\title{
Safety Talk and Check to Prevent Pesticide Toxicity among Farmer
}

\author{
Eka Lestari Mahyuni ${ }^{1}$, Ida Yustina ${ }^{2}$, Etty Sudaryati ${ }^{3}$ \\ ${ }^{1}$ Department of Occupational Safety and Health, Public Health Faculty, University of Sumatera Utara, Indonesia \\ ${ }^{2}$ Department of Administration and Health Policy, Public Health Faculty, University of Sumatera Utara, Indonesia \\ ${ }^{3}$ Department of Nutrition Health, Public Health Faculty, University of Sumatera Utara, Indonesia
}

\section{Article Info \\ Article history: \\ Received Sep 22, 2017 \\ Revised Nov 28, 2017 \\ Accepted Dec 12, 2017}

\section{Keyword:}

Check

Pesticides

Prevention method

Safety talk

Sprayed farmer

\begin{abstract}
The problem at informal sector in particular for farmer when used the pesticides. In Sumber Mufakat village the farmers always use the pesticides without using the safety equipment and have direct contact with the pesticides exposure. The purpose of this research was to apply the safety talk and check method as prevention method to solve the pesticides toxicity that asses from safety and health of pesticide use behaviour. This preventive intervention research was using Participatory Action Research (PAR) design. The data collected by observation, quetionaire, and health check list. The population was all holticultura farmers in Sumber Mufakat village that divide in nine farmer's group. The sample collected by using proportional random sampling. The data will analyze by using qualitative descriptive. The result showed that the implication of safety talk and check method could prevent of pesticide exposure that present from safety and health of pesticides use behaviour. To support the action of safety talk method needed to develop one community that care about the farmers with government endorsement. The check method was very helpful the farmers to identify and predict their health. Both of it could be to cultivate the farmer in safety of pesticide used and early discovery of health symptom cause pesticide used.
\end{abstract}

Copyright () 2017 Institute of Advanced Engineering and Science. All rights reserved.

\section{Corresponding Author:}

Eka Lestari Mahyuni,

Departement of Occupational Safety and Health,

University of Sumatera Utara,

21 Kampus USU, Dr Mansyur Pintu 1, Medan 20155 Indonesia.

Email: eka_mahyuni@ymail.com

\section{INTRODUCTION}

Occupational Safety and Health (OSH) as the one of applied sciences that plays a major role in protecting the workers at the workplace for all aspects of potential hazards and risks that contained in the workplace from raw and materials untill the end of production processed [1], [2]. One of the informal sectors that dominate in Indonesia society is the farming community. The potential hazard in quite serious and has a high risk at the farmers was when using the chemical such as fertilizers and pesticides. It could affect the farmers to exposure and possible poisoning of pesticides [3].

Pesticide exposured such as splashed, spilled, swallowed or inhaled is needed more attention to be chronic or acute toxicity. The most toxicity risk found if the farmers do incorrect use of pesticides with poisoning symptoms and increased levels of cholinesterase enzyme activity in the blood. The symptoms of poisoning experienced can be preceded by dizziness, headache, itches, irritation, and can eventually lead to cancer [4], [5]. Chronic toxicity was more difficult to detect because it's not immediately felt and didn't cause the specific symptoms and signs. However, the chronic toxicity had over long periods of time as the cause of health problems. Some health problems that are often associated with use of pesticides include eye and skin irritation, cancer, miscarriage, defects in infants, as well as neurological, liver, kidney and 
respiratory disorders. Based on a literature study that the impact of exposure of pesticides can lead to multiple myeloma, sarcoma, prostate and pancreatic cancer, uterine cancer, pancreas, breast cancer, neurobehavioral, and Hodgkin [6]-[9].

Sumber Mufakat Village is one of the villages in Kabanjahe sub-district where the dominant farming community cultivates horticultural crops. In increasing production, horticulture farmers use pesticide with high frequency. Based on the result of previous research, is found 6 farmers from 55 who examined showed levels of enzyme cholinesterase close to the allowed limit value. Symptoms of mild to moderate poisoning also felt 51 farmers spraying pesticides. Smoking habits are very high in Sumber Mufakat village community where the majority of 35 peasants smoke 5-50 cigarettes a day. Smoking habits are also often done while spraying pesticides so that the risk of inhalation is very likely to occur, added without the use of personal protection because it feels less comfortable and make the work becomes slower.

The prevention program of pesticides at Karo, especially Sumber Mufakat village is still not done well. The roles of related institutions such as the Agriculture and Health Office have not considered the effects of poisoning due to the use of pesticides. The counseling and assistance on the provision of personal protection or agricultural equipment were the method that accepted by farmer's community. This method of counseling in prevention is ineffective due to the lack of ongoing action on a periodic basis. Other prevention method was also done by farmers in simple action like drinking herbal tea, drinking egg milk tea and taking medicine to relieve dizziness. The actions of farmers when exposure to pesticides like wash their hands or take a bath to clean for relieve symptoms that are felt, but sometimes the symptoms are not gone and will back in a few hour or in one day.

The direct contact with pesticides could not be avoided and the farmers assume which all action have been resolved and become daily habit. This study aims to apply the method of safety talk and check as an effort to overcome pesticide poisoning in farmer community pesticide spraying at Sumber Mufakat Village Karo.

\section{RESEARCH METHOD}

This study was a preventive intervention using Participatory Action Reserach design. Intervention research is a study that provides treatment with a group approach ie treatment is given in packed form which imposed on individuals collectively in the community [10]. The study was conducted in Sumber Mufakat Village, Kabanjahe, Karo District. The study was conducting from February 2016 to September 2017. Population in the research is all horticulture farmers spraying pesticides that exist in Sumber Mufakat Village Kabanjahe, Karo Regency.

Sampling in this research was conducted by probability proportional sampling from nine farmer groups. Sampling technique using proportional random sampling that is as many as 35 people. This research begins by designing the tools of "safety talk and check" method. Before the method was implemented, farmers in the Sumber Mufakat village were socialized about how safety and health behaviors work in the use of pesticides.

The purpose of the training is to equate knowledge and perceptions about the dangers and impacts of pesticide use. The implementation of safety talk and check method was carried out by selecting cadres from each farmer group proportionally and given training on safety talk and check method. The trained cadres then apply the methods of safety talk and check on the farmers in the farming group. Cadres was also accompanied for one week to improve understanding of methods. This implementation activity is then evaluated using a performance achievement questionnaire with a target of at least $25 \%$ of the population understanding and practicing a safe and healthy pesticide use pattern. The data obtained were analyzed qualitative descriptive by explaining how the application of safety talk and check method to farmers.

\section{RESULTS AND ANALYSIS}

Sumber Mufakat Village is located on the cross road of Medan-Kabanjahe and not too far from the city of Berastagi. The agricultural produced in varies from flowering plants, chilli, japan flasks, tomatoes, cabbage, eggplant and so on. Agricultural land is not very wide and almost all the population manages its own farmland. Sumber Mufakat Village still uses chemical-based synthetic pesticides. The application of safety talk and check method to farmers in Sumber Mufakat Village Kabanjahe is done by empowering the community in farmer groups in Sumber Mufakat village. The target farmers or subjects in this study were horticultural farmers, ie farmers who cultivate young plants of vegetables and fruits which use pesticides in frequently than farmers who use pesticides for old or hard crops such as coffee, rubber, and oil palm. 


\subsection{Socialization in occupational safety and health training}

To implement the method of safety talk and check, begin by socialization about how to use the pesticides in safe and health with giving the Occupational Safety and Health training to Sumber Mufakat community. The aim of this training is to reach the same perception about OSH in use of pesticides. The results showed where the farmers in generally know that the exposure to pesticides has been their experience (96\%). But the impact experience is not so visible because the farmers feel in good health. On the other hand, the researchers found some symptoms of pesticide poisoning on the trainees that look like black spots on the skin surface, itching and red on the hands, tired body, eye irritation where all the symptoms are considered farmers as a symptom of poisoning. This conflict of understanding explained that the phenomenon occurs due to exposure of pesticides through subcutaneous (skin), splashing and direct contact during spraying pesticides. The farmers didn't accept if the symptom caused by the pesticides exposure. The farmer considers it common and occurs due to injury at the time of weeding the plants or when spraying pesticides or due to pesticide seepage which is generally cleaned by washing with soap or shower after spraying. Another sign and symptoms always felt but no one of farmers care about it and they suggest that it is usually happened in their life. Actually the symptoms are exactly as the indicator of pesticides exposure [11].

Samely symptoms felt in India that found are the signs and symptoms related to pesticide exposure.The sprayers were asked whether they have experienced these signs and symptoms during or immediately after pesticide spraying. Time of reference for the non-sprayers was while working in the field, during or after pesticide spraying. The signs and symptoms were reported by a large number of sprayers. 277 sprayers (71\%) and $113(29 \%)$ of non sprayers reported at least one of these sign and symptoms. Some of the signs and symptoms with a higher prevalence were excessive sweating (31.8\%), stinging /itching eyes (33.8\%), dry/sore throat (20.5\%), skin redness/white patches (32.8\%), numbness/muscle weakness/muscle cramps $(30.5 \%)$, chest pain/burning sensation $(34.1 \%)$, excessive salivation $(33.1 \%)$. As these signs and symptoms were suo moto reported by the farmers, it was difficult to confirm the occurrence of some of the specific signs or symptoms (like excessive sweating) occurring due to pesticide exposure or because of the tropical hot weather prevailing in the area [12].

Symptoms that are often complained of farmers are fatigue and pain in the body. This fatigue is caused by the duration of holding a spray pump around a land which can took up to 1-3 hours in a day. In addition, many cases are felt by farmers as after them going old and could not spray again because of low back pain, weakened body and shortness of breath. Based on the phenomenon the researchers took the initiative to give one solution by introducing and doing ergonomic gymnastics to reduce pain in the body together in training socialization.

\subsection{Implementation of safety talk and check methods to farmers in sumber mufakat village}

The implementation of safety talks and check method begins with farmer cadre selected from farmer groups in Sumber Mufakat village. The selection of cadres from each farmer group in Sumber Mufakat Village is done by fulfilling the inclusive and exclusive terms proportionally. Each selected cadre is recommended to apply safety talk and check methods to members of the farming group. The number of cadres from each group is presented in Table 1.

Table 1. Number of Cadres and Farmers Applying Safety Talk and Check Methods

\begin{tabular}{clcc}
\hline No & \multicolumn{1}{c}{ Farmer's group Namely } & Amount & Selected Cadre \\
\hline 1 & Rejeki Tani & 27 & 3 \\
2 & Tambar Malem & 35 & 4 \\
3 & Rabu II Pasar & 47 & 5 \\
4 & Arih Ersada I & 65 & 7 \\
5 & Arih Ersada II & 46 & 5 \\
6 & Juma Barung & 22 & 3 \\
7 & Dalan Kutiga I & 32 & 3 \\
8 & Dalan Kutiga II & 31 & 3 \\
9 & Bunga Sumbul & 16 & 3 \\
& Jumlah (total) & 321 & 35 \\
\hline
\end{tabular}

\subsubsection{Application of safety talk method}

Based on the results of the research, each cadre has constraints in delivering safety talk because the farmers who do not care to use pesticides according to the procedure. Safety message delivered to use personal protection during use of pesticides to avoid direct contact with pesticides are denied by farmers because farmers feel disturbed if during use of pesticides using personal protective equipment. This is because farmers feel that for decades they can still work even if they do not use personal protective equipment. 
The phrase can occur because the pesticides used by average farmers are included in the organophosphate group and carbamate. Organophosphat pesticides are pesticides that have a momentary and rapidly degrading effect on the soil, eg Disulfoton, Parathion, Diazinon, Azodrin, Gophacide, and others [13]. Farmers in the Sumber Mufakat village consider the sprayed pesticide to decompose on plants and soil and will not be harmful to health. This is supported by the confidence of farmers that their bodies remain healthy despite decades of spraying. Pesticides will fall to the ground not to their bodies. When it comes to the body, farmers will clean it by washing it with soap or bathing. In this case, farmers do not know that pesticides falling on the soil and polluting the soil can also expose farmers if the pesticides residue included in the food chain. The accumulation of pesticide residues that contaminate agricultural land and enter the food chain, the toxic nature of pesticide materials can lead to various diseases such as cancer, mutation, infant birth defects, CAIDS (Chemically Acquired Deficiency Syndrome) and so on [14].

Farmers in the Sumber Mufakat village admitted to being exposed to pesticides but did not yet know that the negative impact of pesticide use on public health was pesticide poisoning. At the time of spraying, farmers will be exposed to sprinkling pesticides especially if the farmer does not use protective equipment. The farmers will feel some symptoms of poisoning such as nausea, dizziness, weakness, and tears continuously. In Zanzibar found that the farmers who did not use protective measures were more likely to have reported skin irritation and headache, which together with eye irritation, were the most commonly reported acute symptoms [15].

Safety messages in the safety talk conducted more emphasis on the question how the solution to avoid the opposite wind direction when spraying pesticides. Farmers feel that this is dangerous and unavoidable. Splashes on the eyes always occur and sometimes pesticides are also about the body. In reducing direct exposure due to this environment again recommended to use a complete self-protection, especially eye protection. It is a problem because farmers do not have protective goggles or protective clothing as recommended. In general, farmers wear layered clothes and this is not effective because they feel the flow of pesticides that enter into the body through the pores on the clothes used. Exposure to the eyes due to the opposite wind direction often makes the eyes sore and sore [16], [19].

In comparison to the results of research conducted in Ngantru, Tulungagung District shows the behavior of use of Personal Protective Equipment (PPE) to farmers is good enough, but still need to be supervised. Farmers already use masks, hats, long-sleeved shirts and trousers. The peasants use clothing in circles so that they can cover their noses. The use of hat is as a protection from the sun and sprinkling of pesticides on the eyes of farmers. Thus farmers do not need to wear glasses. The use of personal protective equipment is important to use as an effort to avoid direct contact with the pesticide used. Comprehensive and orderly use of PPE is expected to reduce farmers' risks to pesticide poisoning. Poisoning can occur because farmers do not pay attention to guidance on how to use pesticides and how to use personal protective equipment and basic sanitation [17], [20].

From the application of safety talk method farmers feel needed for additional supportive actions because of the safety message delivered. Government support in this case should be done for example by holding an appropriate self-protector to farmers. Based on research, using safety equipment has associate with pesticide toxicity. Health complaints were associated with type of pesticides, behaviour of work clothes use before being washed and inadequate use of personal protective equipments [21]. For the application of the method of continuous safety talk also requires a cadre set as the supervisor of each member of his group to always socialize health messages to farmers during the use of pesticides. It should be noted in the delivery of a safety message that pesticides which have high killing power in low-grade usage leads to less disruption when compared to pesticides with low but high levels of killing power. The lower the LD50 / LC50 value the more toxic the pesticide. In high pesticide toxicity that used will show more symptoms of toxicity that happen on farmers, as same as of volume from pesticide used [22], [23]. For that cadres and farmers must study the chemical hazards of pesticides used and not just buy and use pesticides with high toxicity in order to reduce pests on the plants produced.

\subsubsection{Implementation of check method}

Implementation of check method performed by distributing check sheets containing some health complaints during pesticide use is more effective than the implementation of safety talk method. Farmers are more serious about the health complaints because almost $85 \%$ of the symptoms on the check sheet have been felt by farmers. Farmers who have long used pesticides even consider it familiar with the symptoms and do not consider that the symptoms are toxicity in using pesticides. The reasons stated are usually because they are resistant to the stinging smells of pesticides, dizziness and nausea that are felt in just 15-30 minutes, the hot and sore skin when mixing the pesticides is then reduced after washing with soap, and painful eyes from splashing when spraying and other complaints.

IJPHS Vol. 6, No. 4, December $2017: 293-298$ 
This phenomenon indicates that farmers have been exposed for years and only do self-cleaning to reduce exposure to pesticides such as bathing, hand washing and others. Health checking is never done because farmers think it is still able to work because the symptoms usually disappear at least a day. It can be concluded $85 \%$ of farmers have experienced chronic mild poisoning symptoms. This is due to continuous exposure that lasted for a long time. Continuous exposure is more dangerous than discontinuous exposure at the same time. Even past exposure is worth noting in the event of a new exposure risk. Therefore sprayers that are repeatedly exposed and prolonged may cause chronic poisoning. In many country, farmers showed favourable attitudes about the risk of pesticide usage [22], [24].

These circumstances and behavior should be more attention because farmers still have the old mindset. This understanding may lead to late action when a farmer experiences severe poisoning. Chronic mild poisoning symptoms experienced by farmers can also increase and interfere with the activity of cholinesterase enzymes in the body. Farmers are also aware of the poisoning and there is increased awareness of farmers to check their health. This awareness arises because the farmer feels initially the symptoms are ordinary but the farmer feels afraid because of peer-to-peer experience to experience paralysis and death due to poisoning pesticide. In other hand, the negative pesticides effect on energy metabolism may also damage cell defence against reactive species. It is depent on chemical types including on pesticides. To follow the effect of pesticide poisioning in human body can cause a decrease of cholinesterase levels in the blood. [25], [26].

\section{CONCLUSION}

Safety talk and check was the easy method that help the farmer to prevent the pesticides toxicity. This method could develop the strength of community and detect the symptom of toxicity. Based on the results of research that has been done, it conclouded that application of safety talk method can be implemented comprehensively if supported by the government and the regulatory body to always socialize the message of safety through a stronger media campaign. On the other hand the implementation of check method could increase the awareness of farmers to check their health to be healthy during the use of pesticides. To support this method, the village have to made a periodic biological monitoring as the need of health's farmers. Recommendations that could support the implementation of safety talk and check method is to form the community health care farmers in collaboration with regulatory bodies Karo district so as to set up sanctions and rewards for villages that are able to use safe and healthy pesticides.

\section{ACKNOWLEDGEMENTS}

We would like to thank Mr. Timur Tarigan, Mr. Arianto Sinuhaji, Mr. Mesah, Mr. Rudi Sinukaban and Mr Japet Tarigan whose act as a community leader and coordinator which cooperated in implementing safety talk and check method on farmer community in Sumber Mufakat village. Support of village leader and all farmers who pay attention to the importance of sustainability of the implemented of safety talk and check methods. The researcher is also grateful to the University of North Sumatra who has funded the implementation of this research through TALENTA research program. Researchers hope this safety talk and check method could continue in a sustainable manner with the support of various parties and integrated supervision.

\section{REFERENCES}

[1] "Regulation Number 1, 1970 about Occupational Safety, Regulation of Occupational Safety and Health," Direktorat Jenderal Ketenagakerjaan and Transmigrasi, Jakarta, 2015.

[2] Tarwaka, "Occupational Safety and Health, Occupational Safety and Health Management and Implementation at Workplace," Harapan Offset Surakarta, 2015.

[3] W. Aktar, et. al., "Impact of Pesticides Use in Agriculture; Their Benefits and Hazards," Interdisciplinary Toxicology Journal, vol/issue: 2(1), pp. 1-12, 2009.

[4] R. Quijano and Sarojeni V. R., "Pesticides are Dangerous to your Health, Yayasan Duta Awan," Pesticide Action Network Asia and the Pasific, 1999.

[5] E. L. Mahyuni, "Risk Factors in Pesticides Used against Health Complaints at Farmers in Berastagi Karo District 2014," Journal of KESMAS, vol/issue: 9(1), pp. 79-89, 2015.

[6] Alavanja, et al., "Health effects of Chronic Pesticide Exposure," Cancer and Neurotoxicity Annual Review of Public Health, vol. 25, pp. 155-97, 2009.

[7] T. A. Arcury and S. A. Quandt, "Pesticides at work and at home; Exposure of Migrant Farmworkers," Journal Medical Science, vol/issue: 362(9400), pp. 20-21, 2003.

[8] R. Deborah, "Are pests the Problem or Pesticides," Biology Journal, vol/issue: 28(1), pp. 6-7, 2006.

[9] L. S. Engel, et al., "Pesticide Use and Breast Cancer Risk among Farmer's Wives in the Agricultural Health Study," American Journal of Epidemiology, vol/issue: 161(2), pp. 121-135, 2004. 
[10] A. W. Pratiknya, "Dasar-dasar Metodologi Penelitian Kedokteran dan Kesehatan," PT. Raja Grafindo Persada, Jakarta, 2011.

[11] E. M. Lestari and M. Sinaga, "Health Impact of Pesticides Using Method at Sprayed Worker Farmer in Sumber Mufakat Village, Karo," Advances in Health Sciences Research, Atlantis Press Proceeding 1st Public Health International Conference (PHICo), 2017.

[12] K. R. Dey, et al., "Impact of Pesticide Use on the Health of Farmers; A study in Barak Valley, Assam (India)," Journal of Environmental Chemistry and Ecotoxicology, vol/issue: 5(10), pp. 269-277, 2013.

[13] Sudarmo S., "Pesticides," Kanisius Publisher, Yogyakarta, pp. 15-33, 1991.

[14] Sa'id E. G., "Negative Impacts of Pesticides," A Note to All of us, Agrotek, vol/issue: 2(1), pp. 71-72, 1994.

[15] M. D. Silva, et al., "Pesticide Use and Self Reported Health Symptoms among Rice farmers in Zanzibar," Journal of Agromedicine, vol/issue: 21(4), 2016.

[16] R. Adriyani, "Efforts to Control Environmental Pollution Due to the Use of Agricultural Pesticides," Kesehatan Lingkungan Journal, vol/issue: 3(1), pp. 95-100, 2006.

[17] G. P. Budi, "The Aspects of Improving Pesticide Spraying to Control Plant Disruptive Organisms," Agritech Journal, vol/issue: 11(2), pp. 69-80, 2009.

[18] Raini M., "Toxicology of Pesticides and Treatment Due to Pesticide Poisoning," Media Litbang Kesehatan, $\mathrm{vol} /$ issue: 17(3), 2007.

[19] H. J. Mukono, "Basic principles of Environmental Health," Surabaya, Airlangga University Press, 2006.

[20] E. R. Wismaningsih and D. I. Oktaviasari, "Identification of Pesticides Types and Use of Safety Equipment at Farmers Sprayers in District Ngantru Tulungagung Regency," Journal of Wiyata, vol/issue: 3(1), 2016.

[21] I. A. D. A. Minaka, et al., "Association of Pesticide Use and Personal Protective Equipments with Health Complaints among Horticulture Farmers in Buleleng, Bali," Public Health and Preventive Medicine, vol/issue: 4(1), 2016.

[22] M. Raini, "Toxicology of Pesticides and Treatment Due to Pesticide Poisoning," Media Litbang Kesehatan, vol/issue: XVII(3), pp. 10-18, 2007.

[23] E. S. Pawukir and J. Mariyono, "The Relationship Between Pesticides Use and Health Impact; A Case Study in Highlands of West Sumatera," Journal of Manusia dan Lingkungan, vol/issue: IX(3), pp. 126-136, 2002.

[24] B. Negatu, "Use of Chemical Pesticides in Ethiopia: A cross Sectional Comparative Study on Knowledge, Attitude and Practice of Farmers and Farm Workers in Three Farming Systems," British Occupational Hygiene Society (BOSH), Ann. Occup. Hyg, vol/issue: 60(5), pp. 551-566, 2016.

[25] M. D. Coleman, "A Preliminary Investigation into the Impact of Pesticide Combination on Human Neuronal and Glial Cell Lines in Vitro," PloS ONE, vol/issue: 7(8), 2012.

[26] P. A. Ipmawati, "Analysis of Risk Factors Affecting Pesticide Poisoning Rate at Farmers in Jati Village, Sawangan District, Magelang Regency, Central Java,” Public Health Journal (e-journal), vol/issue: 4(1), pp. 427-435, 2016.

\section{BIOGRAPHIES OF AUTHORS}
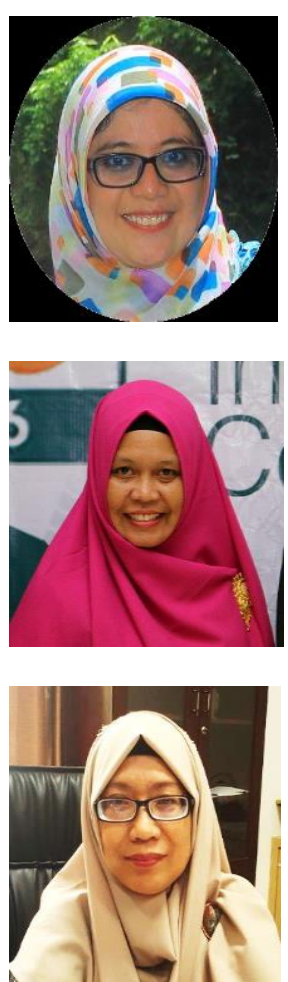

Eka Lestari Mahyuni is a lecture at Occupational Safety and Health Department in Public Health Faculty University of Sumatera Utara since 2005 untill now. She teach about ergonomics, worker nutritions, agriculture health work, industrial physchology, hospital's occupational safety and health and today in concentration about the impact of work environment such pesticides use, physical hazard and chemistry hazard. The rersearch interested done were about, welding worker, pesticide use, hospital acquired infections, and all about design an macro ergonomics. The mobile contact : +6281376287171 with email correspondence eka_mahyuni@ymail.com; e79mahyuni@gmail.com.

Ida Yustina is a lecture at Administration and Health Policy Department in Public Health Faculty University of Sumatera Utara. She is a dean of Faculty of Public Health since 20152020. Her concentration related with this research in how to empowerment the farmers to be health and safe in use the pesticide. The focus teaching in the faculty are related about systemic of thinking, empowerment in health, management startegic and organizational, leadership and health policy. The mobile contact : +6281263024723 with email correspondence: ida_yust@yahoo.com

Etti Sudaryati is a lecture at Health Nutrition Department in Public Health Faculty University of Sumatera Utara. She is a headmaster of Magister and Doctoral Study Program in Public Health faculty. Her concentration related with this research social mobilization to improve the health program where have to use the pesticide in safe and health. The focus concentrated are abou ASI and nutrition consumption and technology. The mobile contact: +6282365777178 with email corresponce: etysudaryati@gmail.com 